\title{
Emotional intelligence as a predictor of employees' career adaptability
}

\author{
Melinde Coetzee and Nisha Harry
}

Department of Industrial and Organisational Psychology, University of South Africa, South Africa

\begin{abstract}
Emotional intelligence and career adaptability are crucial psychosocial meta-capacities for successful adaptation in various spheres of life, including the realm of careers. However, little is known about the relationship between emotional intelligence and Savickas's (2005) notion of career adaptability. The current research examines the relation of emotional intelligence to career adaptability. A cross-sectional survey was conducted with a sample of 409 early career black call center agents (Mean age $=32$ ) employed in three of the largest outsourced financial call centers in Africa. Canonical correlation analysis and structural equation modeling confirmed the predictive validity of emotional intelligence in relation to career adaptability. The results showed that managing one's own emotions contributes the most in explaining overall emotional intelligence a $\mathrm{n} d$ the variance in overall career adaptability with its four domains of career concern, career control, career confidence and career curiosity. The results of the study highlight the importance of developing individuals' emotional intelligence in order to strengthen their career adaptability. The research contributed new and valuable insights that may inform career development interventions for call center agents.
\end{abstract}

\section{Keywords:}

Emotional intelligence Career adaptability Psychosocial meta-capacity Cognitive-affective adaptive functioning

\section{Introduction}

Emotional intelligence and career adaptability are crucial psychosocial metacapacities for successful adaptation in various spheres of life, including the realm of careers. However, little is known about the relationship between emotional intelligence and Savickas's (2005) notion of career adaptability. The current research examines the relation of emotional intelligence to career adaptability. A cross-sectional survey was conducted with a sample of 409 early career black call center agents (Mean age $=32$ ) employed in three of the largest outsourced financial call centers in Africa. Canonical correlation analysis and structural equation modeling confirmed the predictive validity of emotional intelligence in relation to career adaptability. The results showed that managing one's own emotions contributes the most in explaining overall emotional intelligence a $\mathrm{n} d$ the variance in overall career adaptability with its four domains of career concern, career control, career confidence and career curiosity. The results of the study highlight the importance of developing individuals' emotional intelligence in order to strengthen their career adaptability. The research contributed new and valuable insights that may inform career development interventions for call center agents.

In today's global economy, coping with the stress associated with career uncertainty and the unpredictability of ongoing changes requires frequent emotional and cognitive adjustments. To respond effectively to career transitions, individuals must display both emotional intelligence (Yitshaki, 2012) and career adaptability (Savickas, 2005, 2013). People's emotional intelligence is acknowledged 
as a crucial psychosocial meta-capacity for successful adaptation in various spheres of life (Jain, 2012), including the realm of careers (Puffer, 2011). However, research on emotional intelligence as a psychosocial meta-capacity for adapting to the turbulence and stress is limited (Harry \& Coetzee, 2011). There is more evidence that career adaptability is a psychosocial meta-competency required to make effective career transitions. Career adaptability has recently gained momentum as an important psychosocial meta-capacity for coping positively with chaotic employment conditions (Johnston, Luciano, Maggiori, Ruch, \& Rossier, 2013; Porfeli \& Savickas, 2012; Savickas, 2011). Career adaptability represents individuals' resources (attitudes, beliefs and competencies) to respond to potentially stressful work-related situations and challenges (Johnston et al., 2013; Savickas \& Porfeli, 2012).

Research on emotional intelligence and career adaptability has been separately pursued in contexts other than call centers and in relation to various dispositional variables. For example, emotional intelligence has been shown to relate to career commitment (Carson \& Carson, 1998), career self-management (Brown, GeorgeCurran, \& Smith, 2003) and career exploration (Dahl, Austin, Wagner, \& Lukas, 2008; Puffer, 2011). Career adapt-ability ha s been shown t o relate to personality (Teixeira, Bardagi, Lassance, Magalhães, \& Duarte, 2012), employability skills (De Guzman \& Choi, 2013), orientations to happiness and work stress (Johnston et al., 2013), and general and professional well-being (Maggiori, Johnston, Krings, Massopudi, \& Rossier, 2013). The paucity of research to jointly explore these constructs warrants the present study. The present study aimed to add to the extant literature on career development and well-being by investigating whether individuals' emotional intelligence significantly and positively predicts their career adaptability.

We expected that emotional intelligence would positively predict career adaptability. In line with the reasoning of Cobb and Mayer (2000) and Savickas and Porfeli (2012), both constructs are self-regulatory strategies and capacities that serve as important psychosocial resources in the person (psychological) and environment (social) interaction (Savickas \& Porfeli, 2012). Apart from other more stable personality traits that individuals may possess, emotional intelligence and career adaptability are thought to be more malleable cognitive-affective behavioral latent traits and abilities that can be improved through training, counseling, and coaching (Di Fabio \& Kenny, 2011; Di Fabio, Palazzeschi, \& Bar-On, 2012; Johnston et al., 2013; Porfeli \& Savickas, 2012; Savickas, 2005). Research that examines the relationship between emotional intelligence and career adaptability is therefore deemed important because it may inform the design of interventions that help individuals successfully manage their career development and well-being in a demanding work environment.

\section{Theoretical background}

\subsection{Emotional intelligence}

The original ability-trait (mixed) model of emotional intelligence (Salovey \& Mayer, 1990 ) is relevant to the present study. Salovey and Mayer (1990) espouse emotional intelligence as a set of information-processing skills that individuals use to construct reality from emotional stimuli for the purpose of managing life in an adaptive manner (Puffer, 2011). Emotional intelligence is seen as the characteristic ability to perceive and express emotion accurately and adaptively, the ability to understand emotion and emotional knowledge, the ability to use 
feeling to facilitate thought, intellectual growth and problem-solving, and the ability to regulate emotions in oneself and in others (Salovey \& Mayer, 1990). Subsumed under these emotional intelligence abilities are cognitive selfregulatory processes such as an objective awareness and appraisal of one's own and others' feelings, the ability to manage and express these feelings and using emotions to motivate as part of the utilization of emotions (Cobb \& Mayer, 2000). These processes are thought to be important psychological resources for adaptive intrapersonal and interpersonal emotional functioning (Salovey \& Mayer, 1990; Schutte, Malouff, \& Bhullar, 2009).

Mayer, Caruso, and Salovey (2000) conceptualize emotional intelligence as an ability that is similar to cognitive intelligence. According to Caruso, Mayer, and Salovey (2002), emotional functioning forms an integral part of individual's thinking and reasoning (cognitive) functioning and intelligence. However, in contrast to cognitive and social intelligences, Schutte et al. (2008) argue that emotional intelligence can be seen as a latent trait, competency or skill within the individual that may or may not be displayed in the individual's everyday functioning. The underlying assumption is that emotional intelligence provides the potential for performance, rather than performance itself; how individuals would use this latent potential is a matter of personal choice (Jain, 2012).

A handful of researchers emphasize the importance of emotion and emotional intelligence in explaining and understanding career behavior. Kidd (1998) emphasized the role of emotional experience, expression and communication when discussing career decision making. People use both emotional and cognitive abilities when constructing and developing narratives about career (Brown et al., 2003). Carson and Carson (1998) reported a positive relation between individuals' emotional intelligence and their career commitment. Emotion is thought to energize, control and regulate action (Young, Paseluikho, \& Valach, 1997) and therefore needs to be considered in the career self-management and decision-making process (Brown et al., 2003; Schutte et al., 2009). The ability to use emotions to guide one's thinking and actions appears to relate to perceptions and feelings of efficacy in planning and managing career-related actions and tasks (Brown et al., 2003), cognitive task performance (Schutte, Schuettpelz, \& Malouff, 2001) and greater adaptability and emotional functioning (Schutte et al., 2008).

Research shows that emotional intelligence relates positively to less dysfunctional career thinking, greater career decision-making self-efficacy, greater career exploration behavior and career commitment (Dahl et al., 2008; Puffer, 2011). Research by Di Fabio et al. (2012) validates the unique role of emotional intelligence in predicting difficulties in career decision-making. In addition, Di Fabio, Palazzeschi, Asulin-Peretz, and Gati (2013) reported that high emotional intelligence significantly predicts low career indecision for both men and women. Cobb and Mayer (2000) and Goleman (1998) regard emotional intelligence as predictive of success in life and achievement behavior. Research shows that individuals who better understand their feelings are more successful in regulating them and, therefore, achieve higher decision-making performance (Seo \& Barrett, 2007; Yitshaki, 2012). However, despite the amount of research on emotional intelligence in the career context, the predictive validity of emotional intelligence in terms of Savickas's $(2005,2013)$ notion of career adaptability remains unexplored.

\subsection{Career adaptability}

The construct of career adaptability subsumes a set of self-regulatory cognitiveaffective behavioral capacities or psychosocial resources that individuals may draw 
upon to cope with current and anticipated career developmental tasks, occupational transitions, and complex and ill-defined career- and work-related problems

(Savickas \& Porfeli, 2012). The adaptability domains of concern, control, curiosity, and confidence are involved in the translation of individual dispositions into positive career problem-solving and coping behaviors (Johnston et al., 2013; Rossier, Zecca, Stauffer, Maggiori, \& Dauwalder, 2012). These four domains of cognitive-affective behavioral capacities facilitate the realization of personal goals and values irrespective of work conditions that may foster or constrain career development (Lertwannawit, Serirat, \& Pholpantin, 2009).

Career concern refers to the capacity to be aware of and positively oriented to, and plan for a vocational future. Career control reflects the capacity to take personal responsibility for one's career and work experiences, having feelings of selfgoverning, persistence and decisiveness concerning a vocational future. Career curiosity reflects a tendency to explore one's environment and through informationseeking and risk-taking, gain new knowledge and competencies. Career confidence reflects the tendency to feel self-efficacious concerning the ability to master careerrelated challenges and successfully solve problems (De Guzman \& Choi, 2013; Johnston et al., 2013; Savickas \& Porfeli, 2012). Research by Johnston et al. (2013) indicates a negative relationship between career adaptability and work stress and a positive association with orientations to happiness. Johnston et al. (2013) suggest that career adaptability serves as a mechanism through which individuals attain their desired life at work. Porfeli and Savickas (2012) reported a positive association between career adaptability and vocational identity, in-depth career exploration and identification with career commitment.

In line with the theoretical tenets of Mischel's (1973) cognitive-affective processing system theory, we propose that individuals' emotional intelligence predicts their career adaptability. This hypothesis is based on research indicating that individuals with high emotional intelligence have greater adaptive functioning (Schutte et al., 2009), which results from a greater awareness of their emotions and a greater capacity to integrate emotional experience with thoughts and actions (Brown et al., 2003; Emmerling \& Cherniss, 2003).

To test the hypothesis, we recruited employees at a call center. Work in call centers represents a prime example of 21 st century careers with its characteristic uncertainty and frequent transitions (Choi, Cheong, \& Feinberg, 2012; Consiglio, Borgogni, Allesandri, \& Schaufeli, 2013). A call center career is characterized by short-term contracts, vulnerability to shifting markets, and client demands that erode the possibility of long-term employment (Choi et al., 2012). Absenteeism, high turnover rates, little opportunity for career progression, low pay and status, high levels of supervision monitoring and the emotional labor associated with the occupation are also some of the key challenges that call center agents face on a daily basis (Banks \& Roodt, 2011; Borgogni, Consiglio, Allesandri, \& Schaufeli, 2012; Consiglio et al., 2013). Dealing with these challenges requires high levels of emotional intelligence and career adaptability in order for call center agents to cope effectively with the demands of their occupation (Harry \& Coetzee, 2011).

\section{Method}

\subsection{Participants}

The participants were 409 early career Black call center agents employed in three of the largest outsourced financial call centers in Africa. The participants 
consisted of $66 \%$ women and $34 \%$ men. They were predominantly in their early career/life phase with $97 \%$ ranging between $\leq 25$ (47\%) and $\geq 26$ to 40 (50\%) years of age (Mean age $=32$ ).

\subsection{Measures}

\subsubsection{Emotional intelligence}

The Assessing Emotions Scale (AES) developed by Schutte et al. (2009) is a 33-item self-report inventory. A five-point Likert scale $(1=$ strongly disagree; $5=$ strongly agree) is used to measure the following four emotional intelligence traits: perception of emotion (10 items; e.g., "I am aware of my emotions as I experience them"), managing own emotions (9 items; e.g., "I have control over my emotions"), managing others' emotions (8 items; e.g., "I like to share my emotions with others") and utilization of emotions (6 items; e.g., "When my mood changes, I see new possibilities"). Acceptable internal consistency reliabilities were obtained for the present study: perception of emotion (.60), managing own emotions (.73), managing others' emotions (.72), utilization of emotions (.61), and overall emotional intelligence scale (.86).

\subsubsection{Career adaptability}

The Career Adapt-Abilities Scale Form 2. 0 (CAAS) developed by Savickas a n d Porfeli (2012) was used to measure the participants' career adaptability. A 5-point Likert-type scale ( $1=$ not strong; $5=$ strongest) was used for subject responses to each of the items for the following four subscales: concern (6 items; e.g., "Thinking about what my future will be like"), control (6 items); e.g., "Taking responsibility for actions", curiosity (6 items; e.g., "Becoming curious about new opportunities"), and confidence (6 items; e.g., "Performing tasks efficiently"). Acceptable internal consistency reliabilities were obtained for the present study: concern (.76), control (.70), curiosity (.81), confidence (.83) and overall career adaptability scale (.91).

\subsubsection{Demographic variables}

Age and gender were used as control variables. Age was coded $\leq 25$ years $=1$; $\geq 26$ years $=1$. Gender was coded as $0=$ males and $1=$ females.

\section{Procedure}

Ethical clearance and permission for the research were obtained from the Human Resource manager of the call centers involved and the research institution. Questionnaires were distributed to a non-probability purposive sample of 500 call center agents. Each questionnaire included a cover letter inviting respondents to participate voluntarily in the study and assuring them that their individual responses would remain anonymous and confidential. The cover letter also stated that completing the questionnaires and returning them constituted agreement to use the results for research purposes only. The research procedure yielded 409 useable questionnaires (response rate $=82 \%$ ). 


\subsection{Analyses}

Bivariate correlation analyses were calculated to assess the pattern of relationships between the emotional intelligence and career adaptability variables. Canonical correlation analysis was used to further understand the strength of the overall variance shared between emotional intelligence (independent variable) and career adaptability (dependent variable) as two separate variate constructs and the interrelations between the two sets of zeroorder correlations.

Structural equation modeling with the maximum-likelihood (ML) estimation method was used to investigate the structural model fit between emotional intelligence and career adaptability. The goodness-of-fit statistics was evaluated by using the following absolute goodness-of-fit indices: the Chi-square test, the Root Mean Square Error of Approximation (RMSEA), and the Standardized Root Mean Square Residual (SRMR). The following relative goodness-of-fit indices were also used to evaluate the model fit: the Comparative Fit Index (CFI) and the Tucker-Lewis Index (TLI). In line with guidelines provided by Garson (2008), we assumed that an adequate fit of the structural model to the measurement data existed when we obtain CFI and TLI values of .90 or higher, a RMSEA of .08 or lower, and a SRMR of .05 or lower.

\section{Results}

\subsection{Descriptives and correlations}

Table 1 provides an overview of the means, standard deviations, internal consistency reliabilities and correlations between the variables. The emotional intelligence variables significantly and positively correlate with the career adaptability variables $(r \geq .27 \leq .53 ; p \leq .05)$. The zero-order correlations are all well below the level of multi-colinearity concerns $(r \geq .80)$. The correlation results provide an initial indication that further analyses in the form of a canonical correlation analysis to assess the ability of emotional intelligence to predict career adaptability are warranted. 
Table $1 \quad$ Means, standard deviations, reliabilities and bivariate correlations for the study and control variables.

\begin{tabular}{|c|c|c|c|c|c|c|c|c|c|c|c|c|c|c|c|c|}
\hline & & M & SD & $\alpha$ & 1 & 2 & 3 & 4 & 5 & 6 & 7 & 8 & 9 & 10 & 11 & 12 \\
\hline 1. & Age & .54 & .50 & - & - & & & & & & & & & & & \\
\hline 2. & Gender & .65 & .48 & - & $n / s$ & - & & & & & & & & & & \\
\hline 3. & Managing own emotions & 4.31 & .54 & .73 & $n / s$ & $n / s$ & - & & & & & & & & & \\
\hline 4. & Perception of emotions & 3.73 & .52 & .60 & $\begin{array}{l}-.09 \\
\square\end{array}$ & $n / s$ & .44 & - & & & & & & & & \\
\hline 5. & $\begin{array}{l}\text { Managing others' } \\
\text { emotions }\end{array}$ & 3.98 & .63 & .72 & $\mathrm{n} / \mathrm{s}$ & $\begin{array}{l}.04 \\
\square \square\end{array}$ & .65 & .54 & - & & & & & & & \\
\hline 6. & Utilization of emotions & 4.13 & .57 & .61 & $n / s$ & $\begin{array}{l}.11 \\
\square \square\end{array}$ & $\begin{array}{l}.59 \\
\square \square\end{array}$ & $\begin{array}{l}.41 \\
\square \square\end{array}$ & $\begin{array}{l}.53 \\
\square \square\end{array}$ & - & & & & & & \\
\hline 7. & Emotional intelligence & 4.01 & .65 & .86 & $n / s$ & $\begin{array}{l}.10 \\
\square\end{array}$ & .83 & .78 & .86 & $\begin{array}{l}.74 \\
\square \square\end{array}$ & - & & & & & \\
\hline 8. & Concern & 4.32 & .61 & .76 & $n / s$ & $\begin{array}{l}.15 \\
\square \square\end{array}$ & $\begin{array}{l}.48 \\
\square \square\end{array}$ & .33 & $\begin{array}{l}.40 \\
\square \square\end{array}$ & .33 & $\begin{array}{l}.53 \\
\square \square\end{array}$ & - & & & & \\
\hline 9. & Control & 4.19 & .57 & .70 & .11 & .18 & .38 & .26 & .27 & .33 & .43 & .55 & - & & & \\
\hline 10. & Confidence & 4.11 & .65 & .83 & $n / s$ & $n / s$ & .38 & .30 & .36 & .28 & .43 & .50 & .59 & - & & \\
\hline 11. & Curiosity & 4.00 & .69 & .81 & $n / s$ & $n / s$ & $\begin{array}{l}.40 \\
\square \square\end{array}$ & $\begin{array}{l}.31 \\
\square \square\end{array}$ & $\begin{array}{l}.32 \\
\square \square\end{array}$ & $\begin{array}{l}.31 \\
\square \square\end{array}$ & $\begin{array}{l}.47 \\
\square \square\end{array}$ & $\begin{array}{l}.56 \\
\square \square\end{array}$ & $\begin{array}{l}.61 \\
\square \square\end{array}$ & $\begin{array}{l}.66 \\
\square \square\end{array}$ & - & \\
\hline 12. & Career adaptability & 4.16 & .52 & .91 & $n / s$ & $\begin{array}{l}.12 \\
\square \square\end{array}$ & .48 & .35 & $\begin{array}{l}.47 \\
\square \square\end{array}$ & .37 & $\begin{array}{l}.52 \\
\square \square\end{array}$ & .78 & .82 & $\begin{array}{l}.84 \\
\square \square\end{array}$ & $\begin{array}{l}.87 \\
\square \square\end{array}$ & - \\
\hline
\end{tabular}

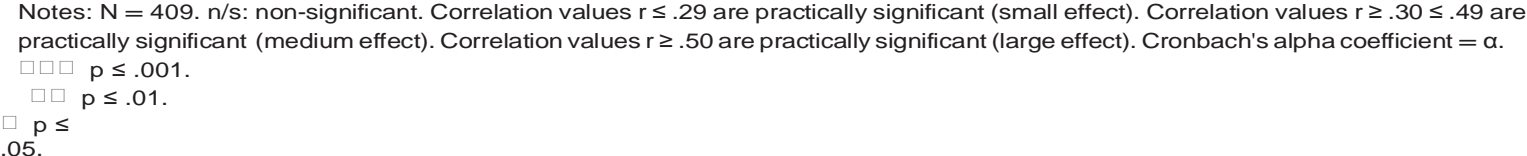

In terms of the control variables, as can be seen from Table 1, the results highlight only a few significant correlations between age and gender and emotional intelligence and career adaptability. However, the associations are small in practical effect size $(r \leq .18)$ and therefore regarded as negligible.

\subsection{Predicting career adaptability from emotional intelligence: canonical correlation analysis}

The canonical correlation analysis revealed that two of the four functions of the full canonical model were significant (Wilks's lambda $(\lambda)=.660$; function 1 : $\mathrm{Fp}=$ $10.84 ; \mathrm{p} \mathrm{b} .0001$; function $2: \mathrm{Fp}=1.90 ; \mathrm{p}=.048)$. Table 2 shows that the full model $\mathrm{r}^{2}$ type effect size (yielded by $1-. \lambda$ ) is .34 (large practical effect), indicating that the full model explains a substantial proportion, about 34\% of the variance shared between the two variable sets. Only the results of the first canonical function were used for analyzing the predictive ability of emotional intelligence because the second function only explained an additional $3 \%\left(\mathrm{Rc}^{2}=.034\right)$ of the full model. Table 1 also shows that the first canonical function already contributes to as much as $91 \%$ of the overall explained variation relative to the two functions.

The redundancy index results summarized in Table 2 shows that emotional intelligence explains $31 \%\left(\mathrm{Rc}^{2}=.31\right.$; large practical effect) of the variance in career adaptability and is able to predict $19.5 \%$ (moderate practical effect) of the proportion of variance in the individual original career adaptability variables. The emotional intelligence variables contribute significantly in explaining the variance in the four original career adaptability variables: career concern $(27 \%)$, career control (16\%), career curiosity (18\%) and career confidence (16\%). Managing own emotions $(\mathrm{Rc}=.53)$ exhibits the highest correlation with the canonical career adaptability variable and is also the strongest predictor of the emotional intelligence canonical construct $(\mathrm{Rc}=.95)$. Career concern $(\mathrm{Rc}=.52)$ exhibits the highest correlation with the canonical emotional intelligence variable and is also the strongest predictor of the career adaptability canonical construct $(R c=.93)$. 


\subsection{Predicting career adaptability from emotional intelligence: structural equation modeling}

Building on the canonical correlation analysis, structural equation modeling was used to further test the overall structural model fit. The fit statistics revealed that the tested model fits the data adequately and that the model can be accepted: Chi (19) = 3.06, RMSEA $=.073$, SRMR $=.04, \mathrm{CFI}=.97, \mathrm{TLI}=.96$. The goodness-of-fit statistics confirm emotional intelligence as a significant predictor of the career adaptability construct $(.63 ; \mathrm{p}=.000)$. The squared multiple correlation data revealed that the model explains $40 \%\left(R^{2}=.40\right.$; large practical effect; $\left.p=.000\right)$ of the variance in the career adaptability construct. Similar to the canonical correlation results, Fig. 1 shows that managing own emotions (.81) and managing others' emotions (.78) contribute the most in explaining the variance in the emotional intelligence construct. Contrary to the canonical correlation results which indicated career concern as the strongest predictor of the career adaptability construct, career curiosity (.83), career control (.82) and career confidence (.82) contribute the most in explaining the variance in the career adaptability construct.

\section{Discussion}

The aim of the present study was to assess whether emotional intelligence significantly and positively predicts career adaptability. The results of the present study support the importance of developing individuals' emotional intelligence in order to enhance their career adaptability.

Table 2 Results of the standardized canonical correlation analysis for the first canonical function.

\begin{tabular}{|c|c|c|c|c|}
\hline Variate/variables & Canonical coefficients & Structure coefficient $(\mathrm{Rc})$ & Canonical cross-loadings & Squared multiple correlations \\
\hline \multicolumn{5}{|c|}{ Emotional intelligence canonical variate variables } \\
\hline Managing own emotions & .673 & .951 & .529 & .281 \\
\hline Perception of emotions & .187 & .643 & .358 & .128 \\
\hline Managing others' & .204 & .788 & .439 & .193 \\
\hline Utilization of emotions & .116 & .678 & .378 & .143 \\
\hline \multicolumn{5}{|c|}{ Career adaptability canonical variate variables } \\
\hline Career concern & .657 & .934 & .521 & .271 \\
\hline Career control & .136 & .728 & .405 & .164 \\
\hline Career curiosity & 189 & .769 & .429 & .184 \\
\hline Career confidence & .195 & .726 & .405 & .164 \\
\hline \multicolumn{5}{|c|}{ Overall model fit measures (function 1): } \\
\hline \multicolumn{5}{|c|}{ Overall $\mathrm{Rc}^{2}=.31$} \\
\hline \multicolumn{5}{|c|}{$F(p)=10.84(p b .0001) ; d f=16 ; 1192.1$} \\
\hline \multicolumn{5}{|c|}{ Overall } \\
\hline \multicolumn{5}{|l|}{ proportion: } \\
\hline \multicolumn{5}{|l|}{.911 Wilks' } \\
\hline \multicolumn{5}{|c|}{$\operatorname{lambda}(\lambda)=$} \\
\hline \multirow{2}{*}{\multicolumn{5}{|c|}{$\begin{array}{l}.660 \\
r^{2} \text { type effect size } 1-. \lambda=.34 \text { (large practical effect) }\end{array}$}} \\
\hline & & ct) & & \\
\hline
\end{tabular}

The results of the present study corroborate previous studies (Brown et al., 2003; Coetzee \& Beukes, 2010; Schutte et al., 2008) which indicate emotional intelligence to be predictive of career decision-making self-efficacy, and vocational exploration and commitment. Overall, the results of the present study provide evidence that high levels of self-efficacious emotional functioning may enhance self-efficacious adaptive functioning in the cognitive-affective behavioral domains of career adaptability. Confidence in one's ability to manage one's own emotions appears to not only increase one's motivation and willingness to plan for a vocational future (career 
concern), take responsibility for one's career and work experiences (career control) and explore one's environment for opportunities (career curiosity) but also seems to lead to greater confidence in mastering the developmental tasks and challenges associated with one's career (career confidence). Managing one's own emotions refers to a sense of emotional self-efficacy, including confidence in the ability to control one's personal emotions, using positive mood to persevere in spite of obstacles and motivate the self to achieve success (Schutte et al., 2009). Emotional self-efficacious functioning has been shown to be important for engaging in problem-solving behaviors and dealing positively with career-related challenges (Brown et al., 2003; Coetzee \& Beukes, 2010; Schutte et al., 2008). The results of the present study also indicated the ability of managing one's own emotions and having high levels of career concern as two important psychosocial career metacapacities in predicting career adaptability. These findings are in line with research conducted by Coetzee and Beukes (2010) which indicates the ability to manage one's own emotions as a significant predictor of the ability to set clear career goals and plans. Salovey and Mayer (1990) also purport that emotions help individuals to generate multiple future plans, improve their decision-making processes (because of a better understanding of one's emotional reaction), facilitate creative thinking and enhance persistence in mastering challenging tasks.

\subsection{Implications for theory and practice}

The significant and positive association between the participants' ability to manage their own emotions and the various domains of their career adaptability highlights the importance of considering emotional intelligence in the career development context. Emotional intelligence is seen to provide the potential for performance (Schutte et al., 2008). As a latent trait, individuals may or may not display emotional intelligence in their everyday functioning (Jain, 2012). On the other hand, Johnston et al. (2013) purport that the behavioral domains of career adaptability assist in translating individual dispositions into positive career problem-solving and coping behaviors. The results of the present study suggest that well-developed emotional intelligence provides the energy, self-regulatory capacity and readiness for displaying positive career adaptability capacities and especially the willingness to plan one's future and how to achieve career goals. Both emotional intelligence and career adaptability are important psychosocial resources for effective career decisionmaking and adaptive functioning (Brown et al., 2003; Savickas \& Porfeli, 2012; Schutte et al., 2009). They are malleable self-regulatory cognitive-affective metacapacities that can be developed through training, coaching and counseling interventions (Johnston et al., 2013; Potgieter, 2012; Savickas, 2005).

\subsection{Limitations}

The present study was limited to a group of predominantly early career Black female call center agents in three large African-based financial call centers. The findings cannot be generalized to other occupational, age and race contexts. Given the cross-sectional nature of the research design, the associations between the variables have been interpreted in an exploratory manner rather than established. Moreover, the potential risk of a common method bias should be considered because of the self-report methodology that was used. However, acceptable internal consistency reliabilities were reported for the two measuring instruments. The findings need to be replicated with broader samples across various occupational, age and race groups and economic sectors before more extensive conclusions can be drawn about the relationship between the constructs of concern to this study. Future research also needs to consider how people's emotional intelligence and career adaptability change over time as their career 
self-concept evolves.

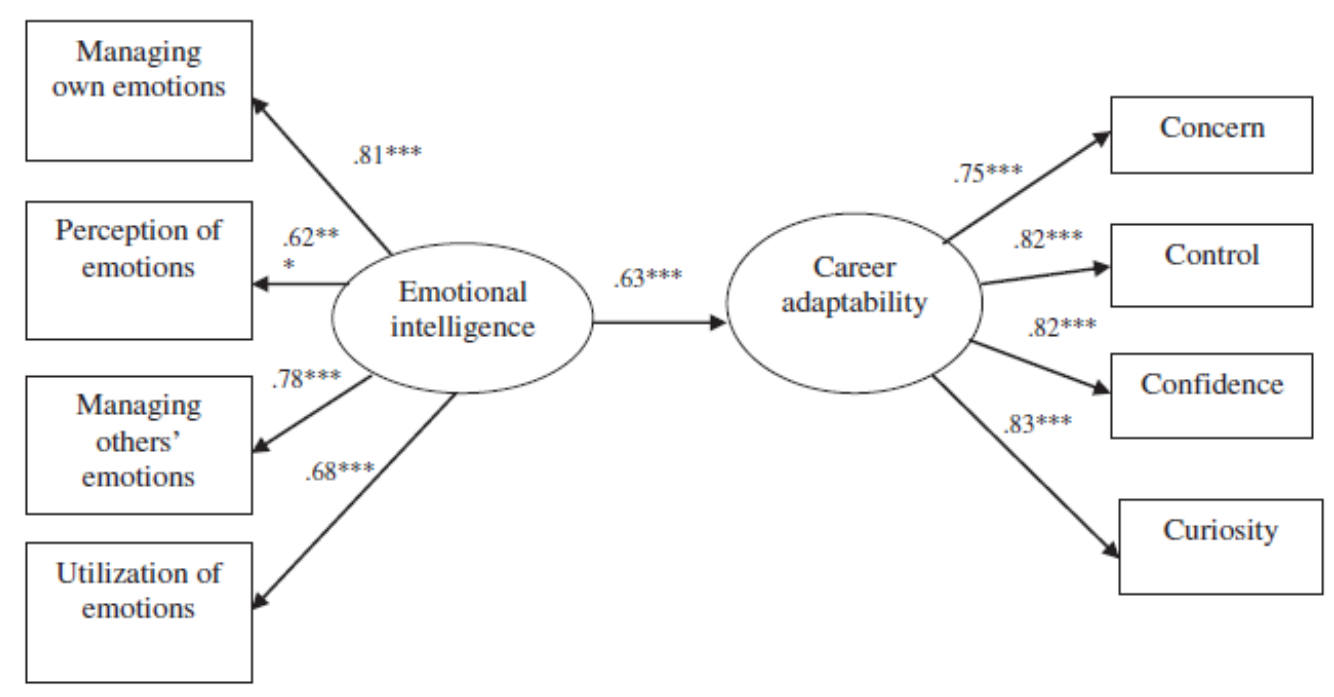

Fig. 1. Emotional intelligence as a predictor of career adaptability. Note: Entries represent standardized regression weights. Structural pathways are significant at the $\mathrm{p}=.001$ and $\mathrm{p}=.01$ levels.

\section{Conclusion}

Notwithstanding the limitations of the study, this research made the novel contribution of applying for the first time the construct of emotional intelligence in relation to Savickas's (2005) notion of career adaptability in the African call center environment. Considering the paucity of research on emotional intelligence and career adaptability in the call center environment, this study contributed valuable new insights that may inform career development interventions for call center agents. The results of the study emphasize the importance of developing call center agents' emotional intelligence in order to strengthen their career adaptability. Attending to interventions that can aid the call center agent in identifying personal strengths in terms of their careerrelated psychosocial meta-capacities (e.g., emotional intelligence and career adaptability) is crucial for dealing with the challenges of the call center occupation.

\section{References}

Banks, D., \& Roodt, G. (2011). The efficiency and quality dilemma: What drives South African call centre management performance indicators? South African Journal of Human Resource Management, 9(1), http://dx.doi.org/10.4102/sajhrm.v9i1.331 (Art. \#331, 17 pages).

Borgogni, L., Consiglio, C., Allesandri, G., \& Schaufeli, W. B. (2012). "Don't throw the baby out with the bathwater": Interpersonal strain at work and burnout.

European Journal of Work \& Organisational Psychology, 21(6), 875-898.

Brown, C., George-Curran, R., \& Smith, M. L. (2003). The role of emotional intelligence in the career commitment and decision-making process. Journal of Career Assessment, 11(4), 379-392.

Carson, K. D., \& Carson, P. P. (1998). Career commitment, competencies, and citizenship. Journal of Career Assessment, 6, 195-208.

Caruso, R., Mayer, J. D., \& Salovey, P. (2002). Relation of an ability measure of 
emotional intelligence to personality. Journal of Personality Assessment, 79, 306320.

Choi, S., Cheong, K. J., \& Feinberg, R. A. (2012). Moderating effects of supervisor support, monetary rewards, and career paths on the relationship between job burnout and turnover intentions in the context of call centers. Managing Service Quality, 22(5), 492-516.

Cobb, C. D., \& Mayer, J. D. (2000). Emotional intelligence: What the research says. Educational Leadership, 58(3), 14-18.

Coetzee, M., \& Beukes, C. (2010). Employability, emotional intelligence and career preparation support satisfaction among adolescents in the school-towork transition phase. Journal of Psychology in Africa, 20(3), 439-446.

Consiglio, C., Borgogni, L., Allesandri, G., \& Schaufeli, W. B. (2013). Does selfefficacy matter for burnout and sickness absenteeism? The mediating role of demands and resources at the individual and team levels. Work and Stress, 27(1), 22-42.

Dahl, A. D., Austin, R. K., Wagner, B. D., \& Lukas, A. (2008). The relationship between negative career thoughts and emotional intelligence. Canadian Journal of Career Development, 7, 4-10.

De Guzman, A. B., \& Choi, K. O. (2013). The relations of employability skills to career adaptability among technical school students. Journal of Vocational Behavior, 82, 199-207.

Di Fabio, A., \& Kenny, M. E. (2011). Promoting emotional intelligence and career decision making among Italian high school students. Journal of Career Assessment, 19(1), 21-34.

Di Fabio, A., Palazzeschi, L., Asulin-Peretz, L., \& Gati, I. (2013). Career indecision versus indecisiveness: Associations with personality traits and emotional intelligence. Journal of Career Assessment, 21(1), 42-56.

Di Fabio, A., Palazzeschi, L., \& Bar-On, R. (2012). The role of personality traits, core self-evaluation, and emotional intelligence in career decisionmaking difficulties. Journal of Employment Counseling, 49, 118-129.

Emmerling, R. J., \& Cherniss, C. (2003). Emotional intelligence and the career choice process. Journal of Career Assessment, 11(2), 153-167.

Garson, G. (2008). Structural equation modeling: Statnotes, PA765.

Retrieved 8 Feb 2012, from.

http://faculty.chass.ncsu.edu/garson/PA765/structur.html

Goleman, D. (1998). Working with emotional intelligence. New York: Bantam Books.

Harry, N., \& Coetzee, M. (2011). Sense of coherence, affective wellbeing and burnout in a South African higher education institution call centre. South African Journal of Labour Relations, 35(2), 26-46.

Jain, A. K. (2012). Does emotional intelligence predict impression management? Journal of Organizational Culture Communications and Conflict, 16(2), 1-14.

Johnston, C. S., Luciano, E. C., Maggiori, C., Ruch, W., \& Rossier, J. (2013). Validation of the German version of the Career Adapt-Abilities Scale and its relation to orientations to happiness and work stress. Journal of Vocational Behavior, 83, 295-304.

Kidd, J. M. (1998). Emotion: An absent presence in career theory. Journal of Vocational Behavior, 52, 275-288.

Lertwannawit, A., Serirat, S., \& Pholpantin, S. (2009). Career competencies and career success of Thai employees in tourism and hospitality sector. The International Business \& Economics Research Journal, 8(11), 65-72.

Maggiori, C., Johnston, C. S., Krings, F., Massoudi, K., \& Rossier, J. (2013). The role of career adaptability and work conditions on general and professional well-being. Journal of Vocational Behavior, 83, 437-449. 
Mayer, J. D., Caruso, D. R., \& Salovey, P. (2000). Selecting a measure of emotional intelligence. The case for ability scales. In R. Bar-On, \& D. A. Parker (Eds.), The handbook of emotional intelligence (pp. 320-342). San Francisco, CA: JosseyBass.

Mischel, W. (1973). Toward a cognitive social learning reconceptualization of personality. Psychological Review, 80, 252-283.

Porfeli, E. J., \& Savickas, M. L. (2012). Career Adapt-Abilities Scale - USA Form: Psychometric properties and relation to vocational identity. Journal of Vocational Behavior, 80, 748-753.

Potgieter, I.L. (2012). The development of a career meta-competency model for sustained employability. (Unpublished doctoral thesis). University of South Africa, Pretoria.

Puffer, K. A. (2011). Emotional intelligence as a salient predictor for collegians' career decision making. Journal of Career Assessment, 19(2), 130-150.

Rossier, R., Zecca, G., Stauffer, S. D., Maggiori, C., \& Dauwalder, J. P. (2012). Career Adapt-Abilities Scale in a French-speaking Swiss sample: Psychometric properties and relationship to personality and work engagement. Journal of Vocational Behavior, 80, 734-743.

Salovey, P., \& Mayer, J. D. (1990). Emotional intelligence. Imagination, Cognition and Personality, 9, 185-211.

Savickas, M. L. (2005). The theory and practice of career construction. In S. D. Brown, \& R. W. Lent (Eds.), Career development and counseling: Putting theory and research to work (pp. 42-70). Hoboken, NJ: John Wiley \& Sons.

Savickas, M. L. (2011). New questions for vocational psychology: Premises, paradigms, and practices. Journal of Career Assessment, 19(3), 251-258.

Savickas, M. L. (2013). Career construction theory and practice. In R. W. Lent, \& S. D. Brown (Eds.), Career development and counseling: Putting theory and research to work (pp. 147-183) (2nd ed.). Hoboken, New Jersey: John Wiley \& Sons.

Savickas, M. L., \& Porfeli, E. J. (2012). Career Adapt-Abilities Scale: Construction, reliability, and measurement equivalence across 13 countries. Journal of Vocational Behavior, 80, 661-673.

Schutte, N. S., Malouff, J. M., \& Bhullar, N. (2009). The Assessing Emotions Scale. In C. Stough, D. Saklofske, \& J. Parker (Eds.), The assessment of emotional intelligence

(pp. 119-135). New York: Springer.

Schutte, N. S., Malouff, J. M., Pric, S., Walter, G., Burke, G., \& Wilkinson, C. (2008). Person-situation interaction in adaptive emotional functioning. Current Psychology, 27(2), 102-111.

Schutte, N. S., Schuettpelz, E., \& Malouff, J. M. (2001). Emotional intelligence and task performance. Imagination, Cognition and Personality, 20, 347-354.

Seo, M., \& Barrett, L. F. (2007). Being emotional during decision-making Good or bad? An empirical investigation. Academy of Management Journal, 50(4), 923-940.

Teixeira, M. A. P., Bardagi, M. P., Lassance, N. C. P., Magalhães, M. D. O., \& Duarte, M. E. (2012). Career Adapt-Abilities Scale - Brazilian Form:

Psychometric

properties and relationship to personality. Journal of Vocational Behavior, 80, 680-685.

Yitshaki, R. (2012). How do entrepreneurs' emotional intelligence and transformational leadership orientation impact new ventures' growth? Journal of Small Business and Entrepreneurship, 25(3), 357-374.

Young, R. A., Paseluikho, M. A., \& Valach, L. (1997). The role of emotion in the construction of career in parent-adolescent conversations. Journal of

Counseling and 
Development, 76, 36-44. 